\title{
Korelasi Kadar Kotinin dan Kolesterol LDL Serum pada Mahasiswa Universitas
} Andalas

\author{
Muhammad Ihsan Fadillah ${ }^{1}$, IImiawati ${ }^{2}$, Eka Fithra Elfi ${ }^{3}$ \\ ${ }^{1}$ Program Studi Profesi Dokter Fakultas Kedokteran Universitas Andalas, Padang \\ ${ }^{2}$ Bagian Farmakologi Fakultas Kedokteran Universitas Andalas, Padang \\ ${ }^{3}$ Bagian Kardiologi dan Kedokteran Vaskuler Fakultas Kedokteran Universitas Andalas, Padang
}

\begin{abstract}
Latar Belakang. Asap rokok dapat memberikan dampak buruk tidak hanya pada perokok aktif tapi juga pada orang yang berada disekitarnya (perokok pasif). Rokok mengandung tembakau, yang memicu pelepasan katekolamin yang mempengaruhi metabolisme lipid. Paparan asap rokok dapat meningkatkan kadar kolesterol LDL serum pada perokok aktif maupun pasif.
\end{abstract}

Objektif. Penelitian ini bertujuan menganalisis korelasi antara kadar kotinin serum (metabolit nikotin) dan kolesterol LDL serum pada dewasa muda.

Metode. Penelitian berdesain potong lintang telah dilakukan, dengan melakukan analisis pada 122 mahasiswa Universitas Andalas berusia 17,5 - 25,9 tahun. Penelitian ini mengumpulkan data demografis, derajat merokok, kadar kotinin serum, dan kadar kolesterol LDL serum. Analisis bivariat dilakukan secara individual pada variabel independen dan perancu terhadap variabel dependen, diikuti analisis regresi hirarkikal berganda.

Hasil. Kadar kotinin serum pada penelitian ini adalah $10.5 \pm$ $6.8 \mathrm{ng} / \mathrm{ml}$ (rerata \pm SD) dan kadar kolesterol LDL adalah $65.5 \pm 18.5 \mathrm{mg} / \mathrm{dl}$ (rerata $\pm S D$ ). Tidak terdapat korelasi signifikan antara kadar kotinin dan kolesterol LDL serum pada analisis bivariat. Akan tetapi, terdapat korelasi nonlinear dengan kadar kolesterol LDL serum pada model regresi yang melibatkan indeks massa tubuh (IMT) sebagai variabel perancu. Nilai adjusted $r 2$ pada penelitian ini adalah 0,066, nilai standardized $\beta$ coefficient variabel IMT sebesar 0,197 ( $p$ $=0,028)$, kotinin serum sebesar $-0,830(p=0,007)$, dan kotinin serum kuadrat sebesar 0,753 $(p=0,014)$.

Kesimpulan. Pada penelitian ini dapat disimpulkan bahwa terdapat korelasi nonlinear antara kadar kotinin dan kolesterol LDL serum dengan melibatkan IMT sebagai variabel perancu pada mahasiswa Universitas Andalas.

Kata kunci: kolesterol, korelasi nonlinear, kotinin, LDL, paparan asap rokok.
Background. Cigarette smoke may cause harm not only to active smokers but also to those in their vicinity (passive smokers). Cigarettes contain nicotine, which triggers the release of catecholamines, affecting lipid metabolism. Exposure to cigarette smoke may increase serum LDL cholesterol levels in active and passive smokers.

Objective. This study aimed to analyze the correlation between serum cotinine (a metabolite of nicotine) and LDL cholesterol levels in young adults.

Methods. A cross-sectional study was performed, the analysis included 122 Andalas University students, aged 17.5 - 25.9 years. Demographic data, smoking degree, serum cotinine, and LDL cholesterol levels were collected. Bivariate analysis was carried out individually on each independent and confounding variables to the dependent variable, followed by multiple hierarchical regressions analysis.

Results. a Serum cotinine levels in this study was 10,5 \pm 6.8 $\mathrm{ng} / \mathrm{ml}$ (mean $\pm S D$ ), and serum $L D L$ cholesterol levels were $65,5 \pm 18,5 \mathrm{mg} / \mathrm{dl}$ (mean $\pm \mathrm{SD}$ ). There was no significant correlation between serum cotinine and LDL cholesterol levels in bivariate analysis. However, serum cotinine levels had a nonlinear correlation with serum LDL cholesterol levels in the regression model that included body mass index (BMI) as the confounding variable. The adjusted $r 2$ value in this study is 0,066 , the standardized $B$ coefficient for the $B M I$ is 0,197 ( $p=$ $0.028)$, for the serum cotinine levels is $-0,830(p=0.007)$, and for the squared serum cotinine levels is $0,753(p=0.014)$.

Keyword: cholesterol, cigarette smoke exposure, cotinine, $L D L$, non-linear correlation. 
Apa yang sudah diketahui tentang topik ini?

Nikotin dimetabolisme oleh hati menjadi kotinin. Nikotin dan kotinin tidak hanya terdapat pada mainstream smoke yang dihirup oleh perokok aktif, tapi juga terdapat pada sidestream smoke dan environmental tobacco smoke yang dihirup oleh perokok aktif. Nikotin memiliki efek pelepasan katekolamin yang dapat mempengaruhi metabolisme lipid.

\section{Apa yang ditambahkan pada studi ini?}

Kotinin serum yang merupakan surrogate marker nikotin, diketahui terdapat pada perokok aktif dan pasif, dan memiliki korelasi positif dengan kadar kolesterol LDL serum yang bersifat korelasi nonlinear.

CORRESPONDING AUTHOR

Phone: +6288271427793

E-mail: ihsannow@hotmail.com

ARTICLE INFORMATION

Received: July $23^{\text {rd }}, 2020$

Revised: April $6^{\text {th }}, 2021$

Available online: May $27^{\text {th }}, 2021$

\section{Pendahuluan}

Merokok merupakan masalah kesehatan di Indonesia yang terjadi pada berbagai tingkat usia penduduk. Berdasarkan data World Health Organization (WHO), perokok aktif usia 15 tahun ke atas jumlahnya meningkat dari $35,7 \%$ pada tahun 2010 hingga 39,5\% pada tahun 2015.1

Jumlah perokok di Provinsi Sumatera Barat mengkhawatirkan, karena berdasarkan data Riset Kesehatan Dasar (Riskesdas) 2013, jumlah perokok aktif dengan frekuensi merokok setiap hari adalah $26,4 \%$, lebih tinggi dari nilai rerata seluruh provinsi di Indonesia, yaitu $24,3 \%{ }^{2}$

Mahasiswa merupakan subpopulasi yang perlu diperhatikan, karena berdasarkan data Riskesdas 2013, jumlah perokok meningkat dari $11,2 \%$ pada rentang usia 11-19 tahun menjadi $27,2 \%$ pada rentang usia 20-24 tahun. ${ }^{2}$

Hal ini semakin mengkhawatirkan karena penelitian yang dilakukan di sembilan negara berbeda di benua Asia menunjukkan terjadi peningkatan jumlah perokok mahasiswa kedokteran dari tahun pertama ke tahun akhir kuliah, yaitu dari $13 \%$ menjadi $24 \%{ }^{3}$

Asap rokok yang ditimbulkan menyebar ke lingkungan dan dapat dihirup oleh orang disekitarnya yang disebut sebagai perokok pasif. Penelitian The Indonesian Medical GHPSS 2006 mendapatkan jumlah perokok pasif mahasiswa kedokteran Indonesia sebesar 79,9\%.4

Asap rokok utama (mainstream smoke) dan sampingan (sidestream smoke) diketahui mengandung nikotin yang dapat memicu perubahan metabolisme lipid lewat mekanisme peningkatan kadar katekolamin serum. ${ }^{5}$

Nikotin asap rokok yang telah masuk ke dalam darah disebut nikotin serum dan berpotensi untuk digunakan mengukur tingkat konsumsi atau paparan asap rokok seseorang. Akan tetapi, nikotin serum memiliki waktu paruh yang singkat, yaitu selama dua jam. ${ }^{6}$

Nikotin dimetabolisme hati menjadi kotinin yang memiliki waktu paruh lebih lama, yaitu selama 20 jam, sehingga dapat digunakan sebagai biomarker pengganti (surrogate biomarker) untuk paparan asap rokok. ${ }^{7}$

Penelitian Attard et al menunjukkan bahwa perokok pasif memiliki resiko terkena hiperkolesterolemia, dimana kadar kolesterol total (TC), rasio TC dengan high-density lipoprotein (HDL), dan trigliserida lebih tinggi pada bukan perokok dan bekas perokok yang terpapar asap rokok di rumah dan di tempat umum daripada orang yang tidak terpapar. ${ }^{8}$

Penelitian komparatif terdahulu di India pada pengguna tembakau, menunjukkan adanya perbedaan parameter metabolisme lipid yang signifikan antara kelompok pengguna dan bukan pengguna tembakau. Pada pengguna tembakau, ditemukan kadar HDL yang lebih rendah, kadar low-density lipoprotein (LDL), very-low density lipoprotein (VLDL), dan trigliserida yang lebih tinggi daripada bukan pengguna tembakau. ${ }^{9}$

Berdasarkan latar belakang diatas, yaitu tingginya prevalensi perokok aktif dan pasif di Indonesia, bahaya yang ditimbulkan asap rokok pada penduduk Indonesia, dan dampak pada perubahan profil lipid khususnya kadar kolesterol LDL, serta belum adanya penelitian korelasi kadar kotinin dan kolesterol LDL serum pada mahasiswa di Indonesia dengan jenis penelitian analitik observasional dengan analisis korelatif antara variabel, maka penulis merasa perlu untuk meneliti bagaimana korelasi kadar kotinin dan kolesterol LDL serum pada mahasiswa Universitas Andalas. 


\section{Metode}

Penelitian ini menggunakan desain potong lintang, dimana dilakukan pengukuran pada waktu yang bersamaan pada kadar kotinin serum sebagai variabel bebas dan kadar kolesterol LDL serum sebagai variabel terikat. Populasi penelitian ini adalah subyek dewasa muda mahasiswa Universitas Andalas. kriteria inklusi penelitian ini adalah mahasiswa Universitas Andalas, berusia 18-22 tahun, dan memiliki data variabel independen, dependen, serta variabel perancu dalam tabel master. Kriteria eksklusi penelitian ini adalah memiliki riwayat penyakit hiperkolesterolemia dan mengonsumsi obat pengontrol kadar kolesterol serum.

Sampel penelitian ini adalah bagian dari populasi yang memenuhi kriteria inklusi dan tidak memenuhi kriteria eksklusi. Besar sampel ditentukan berdasarkan rumus Green yang sesuai dengan penelitian yang menggunakan analisis multivariabel. ${ }^{10}$

Variabel independen penelitian: kadar kotinin serum mahasiswa Universitas Andalas. Variabel dependen penelitian: kadar kolesterol LDL serum. variabel perancu penelitian: usia, jenis kelamin, IMT, dan skor Indeks Brinkmann.

Penelitian ini menggunakan data sekunder berupa tabel master yang didapatkan dari penelitian terdahulu oleh dr. Ilmiawati, Ph.D yang telah dilakukan pada tahun 2018 dengan judul "Survei Paparan Kadmium (Cd) sebagai Faktor Resiko Aterosklerosis dan Hubungannya dengan Ketebalan Lapisan Intima-Media Arteri Karotis pada Subjek Dewasa Muda yang Tinggal di Padang, Indonesia". ${ }^{11}$

Data sekunder yang telah didapat dilakukan analisis univariat, bivariat, dan multivariabel dengan menggunakan program IBM SPSS Statistics 23. Analisis bivariat menggunakan uji Spearman, sementara analisis multivariabel menggunakan uji regresi berganda.

\section{Hasil}

Hasil penelitian diperoleh berdasarkan observasi data sekunder subyek pada variabel kadar kotinin serum, kadar kolesterol LDL serum, dan variabel perancu. Hasil analisis univariat pada data demografis subyek penelitian dapat dilihat pada tabel berikut:
Tabel 1. Karakteristik subyek penelitian $(n=122)$.

\begin{tabular}{|c|c|c|c|c|}
\hline \multirow{2}{*}{ Variabel } & \multirow{2}{*}{ Semua } & \multicolumn{2}{|c|}{ Jenis Kelamin } & \multirow{2}{*}{ Nilai p } \\
\hline & & Pria & Wanita & \\
\hline Jumlah (\%) & $\begin{array}{c}122 \\
(100)\end{array}$ & $62(50,8)$ & $60(49,2)$ & \\
\hline \multicolumn{5}{|l|}{ Usia (tahun) } \\
\hline Rerata (SD) & 20,8 & $20,9(1,4)$ & $20,8(1,2)$ & 0,97 \\
\hline Median & 20,9 & 21,0 & 20,9 & \\
\hline Rentang & $\begin{array}{c}17,5- \\
25,9\end{array}$ & $18,0-25,9$ & $\begin{array}{c}17,5- \\
23,3\end{array}$ & \\
\hline \multicolumn{5}{|l|}{ IMT $\left(\mathrm{kg} / \mathrm{m}^{2}\right)$} \\
\hline Rerata (SD) & $\begin{array}{l}22,9 \\
(4,3)\end{array}$ & $23,6(4,8)$ & $22,1(3,6)$ & 0,16 \\
\hline Median & 21,7 & 22,3 & 21,1 & \\
\hline Rentang & $\begin{array}{c}16,9- \\
40,8\end{array}$ & $17,8-40,8$ & $\begin{array}{c}16,9- \\
33,8\end{array}$ & \\
\hline \multicolumn{5}{|c|}{ Kategori IMT (n, (\%)) } \\
\hline Kurus & $16(13,7)$ & $6(11,3)$ & $10(16,1)$ & \\
\hline Normal & $58(46,8)$ & $29(45,2)$ & $29(48,3)$ & \\
\hline Gemuk & $1714,5)$ & $7(11,3)$ & $10(16,7)$ & \\
\hline Obesitas & $31(25)$ & $20(32,3)$ & $11(18,3)$ & \\
\hline
\end{tabular}

Indeks Brinkmann (skor Indeks Brinkmann, (\%))

$\begin{array}{lcccc}\text { Rerata (SD) } & 5,3 & & & \mathrm{p}<0,001 \\ \text { Median } & (14,0) & 10,5(18,1) & 0,0(0,0) & \\ & 0,0 & 0,0 & 0,0 & \\ \text { Rentang } & 00,0- & 0,0-75,0 & & \end{array}$

\begin{tabular}{|c|c|c|c|c|}
\hline \multicolumn{5}{|c|}{ Kategori Indeks Brinkmann (n, (\%)) } \\
\hline $\begin{array}{l}\text { Perokok } \\
\text { ringan }\end{array}$ & $26(21,3)$ & $26(41,9)$ & $0(0)$ & $\mathrm{p}<0,001$ \\
\hline $\begin{array}{l}\text { Perokok } \\
\text { sedang }\end{array}$ & $0(0)$ & 0 & 0 & \\
\hline $\begin{array}{l}\text { Perokok } \\
\text { berat }\end{array}$ & $0(0)$ & 0 & 0 & \\
\hline
\end{tabular}

Paparan asap rokok lingkungan $(\mathrm{n},(\%))$ 0,001

Tak ada paparan

Jarang Kadang-

kadang $11(9,0) \quad 7(11,3) \quad 4(6,7)$ Sering $29(23,8) 24(38,7) \quad 5(8,3)$ 76
$(62,3)$ $27(43,5) \quad 49(81,7)$ $6(4,9) \quad 4(6,5) \quad 2(3,3)$

Hasil analisis univariat pada variabel independen dan dependen subyek penelitian dapat dilihat pada tabel berikut:

Tabel 2. Rerata kadar kotinin dan kolesterol LDL serum subyek ( $\mathrm{n}=122)$.

\begin{tabular}{lcccl}
\hline \multirow{2}{*}{ Variabel } & \multirow{2}{*}{ Semua } & \multicolumn{2}{l}{ Jenis Kelamin } & Nilai \\
& & Pria & Wanita & p \\
\hline Kadar Kotinin & Serum & & & \\
(ng/mL) & & & & \\
$\quad$ Rerata (SD) & $10,5(6,8)$ & $10,9(7,3)$ & $10,1(6,3)$ & 0,54 \\
Median & 10,8 & 11,3 & 10,3 & \\
Rentang & $0,9-24,7$ & $0,9-24,7$ & $1,0-23,8$ &
\end{tabular}




\begin{tabular}{lcccc}
\multirow{2}{*}{ Variabel } & Semua & \multicolumn{2}{c}{ Jenis Kelamin } & Nilai \\
\cline { 3 - 4 } & & Pria & Wanita & p \\
\hline IMT (kg/m²) & & & & \\
Rerata (SD) & 65,5 & & 63,9 & 0,54 \\
\multirow{2}{*}{ Median } & $(18,6)$ & $67,0(19,6)$ & $(17,5)$ & \\
& 60,3 & 61,2 & 63,9 & \\
Rentang & $18,2-$ & $18,2-$ & $22,7-$ & \\
& 115,6 & 15,6 & 104,0 & \\
\hline
\end{tabular}

Berdasarkan uji normalitas, didapatkan variabel kadar kotinin serum tidak terdistribusi normal. Setelah dilakukan transformasi data, variabel independen juga tidak terdistribusi normal.

Untuk mengetahui korelasi kadar kotinin dan kolesterol LDL serum, dilakukan analisis bivariat menggunakan uji Spearman. Hasil analisis disajikan dalam gambar berikut:

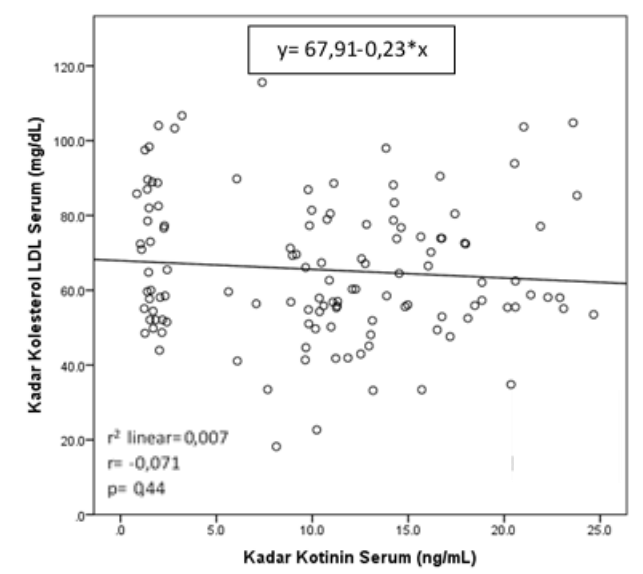

Gambar 1. Korelasi kadar kotinin (ng/mL) dan kolesterol LDL serum (mg/dL) $(\mathrm{n}=122)$.

Untuk mengetahui adanya korelasi nonlinear, maka dilakukan prosedur pemeriksaan jenis korelasi dengan uji kurva estimasi, yang melihat korelasi nilai prediksi dan nilai observasi kadar kolesterol LDL serum. Hasil uji kurva estimasi disajikan dalam gambar berikut:

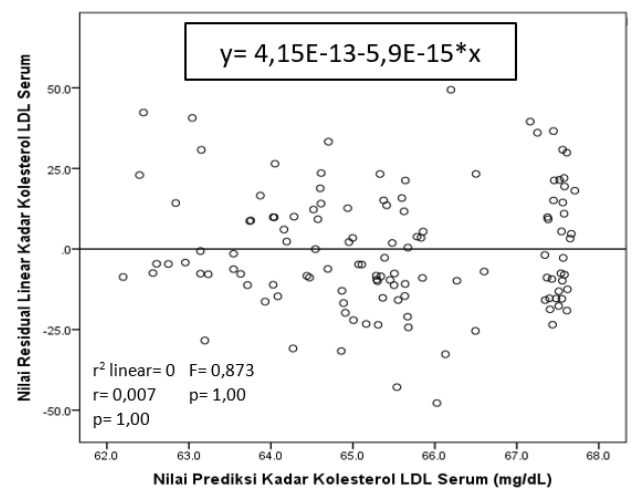

Gambar 2. Korelasi nilai prediksi kolesterol LDL (ng/mL) kurva linear dengan nilai residual berdasarkan analisis regresi linear $(n=122)$.

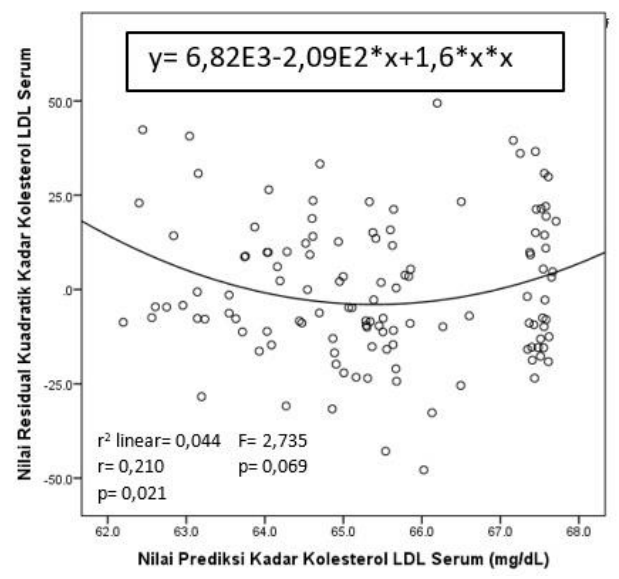

Gambar 3. Korelasi nilai prediksi kolesterol LDL kurva kuadratik dengan nilai residual, hasil analisis regresi linear $(n=122)$.

Uji kurva estimasi menunjukkan korelasi antara variabel independen dan dependen bersifat nonlinear.

Hubungan kadar kotinin dan kolesterol LDL serum pada analisis multivariabel menggunakan analisis nonlinear, yaitu kurva estimasi, didapatkan hasil yang disajikan dalam gambar berikut:

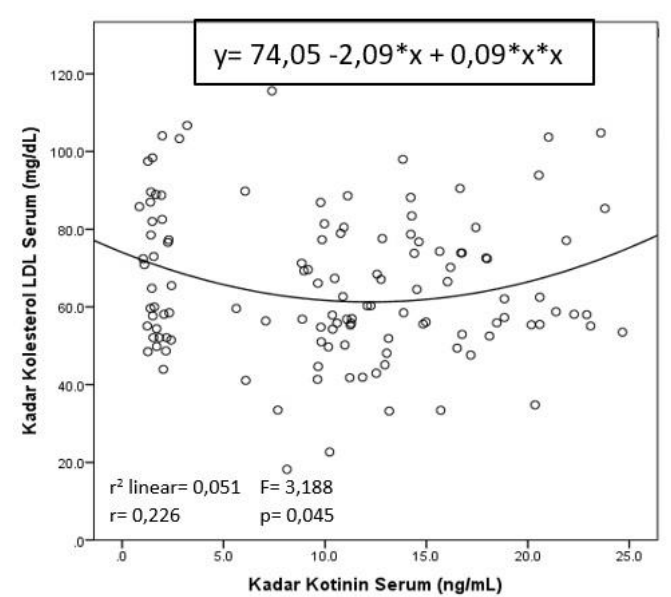

Gambar 4. Korelasi nilai prediksi kolesterol LDL (ng/mL) kurva kuadratik dengan nilai residual, hasil analisis regresi linear $(n=122)$.

Nilai adjusted $r^{2}$, standardized $\beta$ coefficient, dan nilai $\mathrm{p}$ untuk variabel independen dan perancu disajikan dalam tabel berikut. 
Tabel 3. Rerata kadar kotinin dan kolesterol LDL serum subyek $(\mathrm{n}=122)$.

\begin{tabular}{|c|c|c|c|c|}
\hline & $\begin{array}{l}\text { Adjuste } \\
\text { d } \mathbf{r}^{2}\end{array}$ & $\begin{array}{l}\text { Predikto } \\
\mathbf{r}\end{array}$ & $\begin{array}{l}\text { Standardize } \\
\text { d } \beta \\
\text { coefficient }\end{array}$ & $\begin{array}{l}\text { Nilai } \\
\text { p }\end{array}$ \\
\hline \multirow{9}{*}{$\begin{array}{l}\text { Kolester } \\
\text { ol LDL } \\
(\mathrm{mg} / \mathrm{dL})\end{array}$} & \multirow{9}{*}{0,053} & Usia & $-0,037$ & $\begin{array}{l}0,69 \\
8\end{array}$ \\
\hline & & Jenis & \multirow[t]{2}{*}{0,015} & 0,87 \\
\hline & & $\begin{array}{l}\text { Kelamin } \\
\text { Indeks }\end{array}$ & & \\
\hline & & Massa & \multirow[t]{2}{*}{0,209} & $\begin{array}{l}0,03 \\
0\end{array}$ \\
\hline & & $\begin{array}{l}\text { Tubuh } \\
\text { Indeks }\end{array}$ & & \\
\hline & & Brinkman & 0,111 & $\begin{array}{l}0,26 \\
6\end{array}$ \\
\hline & & Kotinin & \multirow{2}{*}{$-0,886$} & 0,00 \\
\hline & & Serum & & 5 \\
\hline & & $\begin{array}{l}\text { Kotinin } \\
\text { Serum } \\
\text { (kuadrat) }\end{array}$ & 0,791 & $\begin{array}{l}0,01 \\
2\end{array}$ \\
\hline \multirow{8}{*}{$\begin{array}{l}\text { Kolester } \\
\text { ol LDL } \\
(\mathrm{mg} / \mathrm{dL})\end{array}$} & \multirow{8}{*}{0,061} & Usia & $-0,036$ & $\begin{array}{l}0,70 \\
5\end{array}$ \\
\hline & & Indeks & \multirow{3}{*}{0,206} & 0,02 \\
\hline & & Massa & & 9 \\
\hline & & $\begin{array}{l}\text { Tubuh } \\
\text { Skor }\end{array}$ & & \\
\hline & & $\begin{array}{l}\text { Indeks } \\
\text { Brinkman } \\
\mathrm{n}\end{array}$ & 0,105 & $\begin{array}{l}0,25 \\
0\end{array}$ \\
\hline & & Kotinin & \multirow{2}{*}{$-0,876$} & 0,00 \\
\hline & & Serum & & 5 \\
\hline & & $\begin{array}{l}\text { Kotinin } \\
\text { Serum } \\
\text { (kuadrat) }\end{array}$ & 0,782 & $\begin{array}{l}0,01 \\
1\end{array}$ \\
\hline \multirow{10}{*}{$\begin{array}{l}\text { Kolester } \\
\text { ol LDL } \\
(\mathrm{mg} / \mathrm{dL})\end{array}$} & \multirow{10}{*}{0,068} & Indeks & \multirow{4}{*}{0,196} & 0.02 \\
\hline & & Massa & & 9 \\
\hline & & Tubuh & & \\
\hline & & Skor & & \\
\hline & & Indeks & \multirow{2}{*}{0,099} & 0,27 \\
\hline & & $\begin{array}{l}\text { Brinkman } \\
\mathrm{n}\end{array}$ & & 0 \\
\hline & & Kotinin & \multirow{2}{*}{$-0,875$} & 0,00 \\
\hline & & Serum & & 5 \\
\hline & & Kotinin & \multirow[b]{2}{*}{0,788} & 0,01 \\
\hline & & $\begin{array}{l}\text { Serum } \\
\text { (kuadrat) }\end{array}$ & & 0 \\
\hline \multirow{6}{*}{$\begin{array}{l}\text { Kolester } \\
\text { ol LDL } \\
(\mathrm{mg} / \mathrm{dL})\end{array}$} & \multirow{6}{*}{0,066} & Indeks & \multirow{3}{*}{0,197} & \\
\hline & & Massa & & $\begin{array}{l}8,02 \\
8\end{array}$ \\
\hline & & Tubuh & & \\
\hline & & Kotinin & \multirow{2}{*}{$-0,830$} & 0,00 \\
\hline & & Serum & & 7 \\
\hline & & $\begin{array}{l}\text { Kotinin } \\
\text { Serum } \\
\text { (kuadrat) }\end{array}$ & 0,753 & $\begin{array}{l}0,01 \\
4\end{array}$ \\
\hline
\end{tabular}

\section{Pembahasan}

Berdasarkan uji normalitas, didapatkan variabel usia terdistribusi normal, sementara https://doi.org/10.25077/jikesi.v1i3.67 variabel jenis kelamin, IMT, paparan asap rokok, dan indeks Brinkmann tidak. Dari hasil uji t-test independen pada variabel usia dan uji MannWhitney U pada variabel IMT, tidak terdapat perbedaan antara pria dan wanita yang bermakna, sementara pada indeks Brinkmann dan paparan asap rokok, terdapat perbedaan bermakna.

Tabel 1 menunjukkan subyek penelitian memiliki rerata \pm SD usia $20,8 \pm 1,3$ tahun, dengan usia termuda adalah 17,5 tahun dan usia tertua yaitu 25,9 tahun. Berdasarkan rerata usia responden dapat kita simpulkan bahwa responden tergolong dalam kelompok dewasa muda. Hal ini sejalan dengan penelitian potong lintang pada subyek bukan perokok dan perokok di Amerika Serikat yang subyeknya berusia 20 tahun atau lebih. ${ }^{12}$

Pada penelitian ini, tidak didapatkan hubungan bermakna antara usia dan kadar kolesterol LDL sebesar 0,060 $(p=0,512)$. Hasil berbeda didapatkan penelitian Lind et al. (2018) yang menemukan penurunan kadar kolesterol LDL pada tiap peningkatan kelompok usia. ${ }^{13}$ Penelitian ini tidak sejalan dengan penelitian Abbott (1983) pada subyek rentang usia 20 sampai 50 tahun, dimana terdapat peningkatan kadar kolesterol LDL serum dan pria lebih tinggi peningkatannya dibandingkan wanita. ${ }^{14}$ Tidak adanya hubungan ditemukan pada penelitian ini mungkin disebabkan oleh rentang usia subyek yang sempit, yaitu antara 17,5 tahun sampai 25,9 tahun.

Pada awal penelitian ini, sampel dibagi dengan jumlah yang sama antara pria dan wanita karena ada keterbatasan kit cotinine test, sehingga didapatkan pria dan wanita masing-masing 62 sampel. Pada proses pengolahan data, dilakukan eksklusi 2 sampel wanita karena data master tabel sampel tersebut tidak lengkap.

Penelitian ini menemukan rerata kadar kolesterol LDL serum pria dan wanita berbeda tapi tidak signifikan. Kadar kolesterol wanita premenopause lebih rendah dari pria dikarenakan adanya estrogen, yang berkaitan dengan peningkatan laju katabolik partikel kolesterol LDL yang lebih tinggi dibandingkan laju produksinya. ${ }^{15}$ Penelitian Jain dan Ducatman (2018) menemukan pria memiliki kemungkinan lebih tinggi terjadinya abnormalitas LDL sebesar 1,113 kali dan abnormalitas trigliserida sebesar 1,48 kali. $^{16}$ 
Klasifikasi derajat merokok yang digunakan dalam penelitian ini adalah indeks Brinkmann, yaitu perkalian tahun merokok dengan rerata jumlah batang rokok perhari. Pembagian ini menentukan seseorang termasuk perokok ringan, sedang, atau berat. Analisis univariat mendapatkan semua perokok aktif termasuk perokok ringan, sehingga tidak dapat dilakukan analisis korelasi berdasarkan kategori derajat perokok.

Hasil analisis bivariat uji Spearman pada hubungan derajat merokok dengan kadar kolesterol LDL serum mendapatkan hubungan sebesar $-0,059$ yang tidak bermakna $(p=0,517)$. Hasil penelitian ini sejalan dengan penelitian di China, dimana tidak ditemukan perbedaan kadar kolesterol LDL serum yang signifikan pada perokok dengan kebiasaan merokok ringan, sedang, dan berat. Kategori perokok penelitian ini berdasarkan jumlah rokok yang dikonsumsi perhari, sementara subyek terbanyak berasal dari perokok ringan. ${ }^{17}$ Penelitian tentang kebiasaan merokok juga dilakukan oleh Rashan et al. (2016) tapi dengan hasil perbedaan yang bermakna antara perokok ringan, sedang, dan berat. ${ }^{18}$

Tabel 1 menunjukkan nilai dan kategori IMT subyek penelitian. Berdasarkan nilai IMT, subyek memiliki nilai rerata \pm SD sebesar $22,9 \pm 4,3 \mathrm{~kg} / \mathrm{m} 2$. Berdasarkan kategori IMT, subyek paling banyak memiliki IMT normal dengan jumlah 58 orang.

Penelitian ini mendapatkan nilai IMT para subyek beragam dan analisis univariat mendapatkan subyek menempati setiap kategori IMT, dimana pada subyek pria dan wanita terbanyak memiliki IMT normal. Hasil uji Spearman mendapatkan nilai korelasi IMT dan kolesterol LDL tidak bermakna sebesar 0,123 ( $\mathrm{p}=$ 0,177). Hasil korelasi ini berbeda dengan penelitian Jain dan Ducatman (2018), dimana IMT berkorelasi dengan kolesterol LDL. Satu unit peningkatan IMT berkorelasi dengan peningkatan $0,18 \%$ kolesterol LDL dengan nilai yang bermakna. ${ }^{16}$

Penelitian ini mendapatkan rerata kadar kotinin serum subyek mahasiswa adalah $10,5 \pm 6,8$ $\mathrm{ng} / \mathrm{mL}$, dimana kadar kotinin pria adalah $10,9 \pm 7,3$ $\mathrm{ng} / \mathrm{mL}$ yang nilainya lebih tinggi daripada wanita, yaitu 10,1 $\pm 6,3 \mathrm{ng} / \mathrm{mL}$. Perbedaan kadar kotinin serum pria dan wanita ini tidak bermakna berdasarkan analisis univariat uji Mann-Whitney U.
Hasil penelitian ini berbeda dengan penelitian Baltar et al. (2011), dimana pria memiliki kadar kotinin lebih tinggi sebesar $0,25 \mathrm{ng} / \mathrm{mL}$ dengan nilai signifikansi $p=0,04$ daripada wanita. ${ }^{19}$ Penelitian Benowitz mendapatkan hasil yang unik, di mana pada kelompok subyek usia 12-19 tahun terdapat perbedaan, yaitu rerata kadar kotinin pria sebesar $54,41 \mathrm{ng} / \mathrm{mL}$ dan wanita sebesar $33,42 \mathrm{ng} / \mathrm{mL}$, sementara pada kelompok subyek usia 20 tahun ke atas tidak terdapat perbedaan, dengan nilai kotinin pria sebesar $122,08 \mathrm{ng} / \mathrm{mL}$ dan wanita sebesar $122,72 \mathrm{ng} / \mathrm{mL}^{20}$

Kadar kotinin serum seseorang dapat meningkat atau menurun tergantung ada atau tidaknya faktor yang mempengaruhi. Faktor yang mempengaruhi adalah faktor genetik, yaitu aktivitas enzim CYP2A6 yang dapat diinduksi atau diinhibisi oleh berbagai faktor, faktor variasi aktivitas ekskresi kotinin ginjal, dan faktor diet berupa konsumsi brokoli dan jus jeruk bali.21,22,23

Tabel 5.2 menunjukkan rerata \pm SD kolesterol LDL adalah $65,5 \pm 18,5 \mathrm{mg} / \mathrm{dL}$ dan termasuk ke dalam kategori optimal, yaitu dibawah 100 mg/dL. ${ }^{24}$ Hasil uji t-test independen menunjukkan tidak terdapat perbedaan bermakna pada kadar kolesterol LDL serum pria dan wanita.

Penelitian ini menemukan rerata \pm SD kadar kolesterol LDL subyek adalah $65,5 \pm 18,5 \mathrm{mg} / \mathrm{dL}$ dengan nilai median $60,3 \mathrm{mg} / \mathrm{dL}$. Terdapat hasil yang lebih tinggi pada penelitian Merianos et al. (2017) pada subyek remaja usia 12-19 tahun, dimana kadar rerata subyek dengan kotinin serum $<0,05 \mathrm{ng} / \mathrm{mL}$ sebesar $88,34 \pm 1,30 \mathrm{ng} / \mathrm{mL}$, kadar 0,05-2,99 $\mathrm{ng} / \mathrm{mL}$ sebesar 92 dan $>2,99$ $\mathrm{ng} / \mathrm{mL}$ sebesar 86,82 $\pm 1,64 \quad \mathrm{ng} / \mathrm{mL}^{25}$ Kadar kolesterol LDL serum seseorang dipengaruhi oleh faktor diet, yaitu konsumsi lipid, khususnya asam lemak jenuh, dan kurangnya aktivitas. ${ }^{26}$ Subyek penelitian tersebut diketahui mengkonsumsi lemak yang kadarnya lebih tinggi dari angka kecukupan gizi (AKG) yang disarankan berdasarkan PMK no. 28 tahun 2019. ${ }^{27}$ Karakteristik subyek penelitian juga menunjukkan subyek memiliki tingkat aktivitas yang rendah sampai tidak ada.

Kadar kotinin serum dapat digunakan untuk memprediksi gangguan fungsi tubuh akibat rokok, salah satunya adalah kadar kolesterol LDL, karena kotinin yang didapat seseorang merupakan hasil metabolisme zat nikotin dari paparan asap rokok sebelumnya, baik perokok aktif ataupun pasif. 25,28 
Penelitian ini mendapatkan korelasi negatif yang tidak bermakna antara kadar kotinin dan kolesterol LDL serum $(p=0,432)$. Hasil ini sejalan dengan penelitian komparatif oleh Kim et al. (2017) dimana peningkatan kadar kotinin pada tiap kuartil tidak berkorelasi positif dengan kadar kolesterol LDL $\quad(\mathrm{Q} 1=115,2 \pm 1,1 \mathrm{ng} / \mathrm{mL}, \mathrm{Q} 2=$ $117,4 \pm 1,3 \mathrm{ng} / \mathrm{mL}, \mathrm{Q} 3=115,5 \pm 1,2 \mathrm{ng} / \mathrm{mL}, \mathrm{Q} 4=$ $112,5 \pm 1,2 \mathrm{ng} / \mathrm{mL}, \mathrm{p}=0,047) .{ }^{29}$

Analisis bivariat tidak berhasil mendapatkan korelasi yang bermakna, sehingga dilakukan analisis multivariabel untuk mendapatkan kurva korelasi yang memiliki nilai bermakna dan variabel independen yang mempengaruhinya. Analisis multivariabel penelitian ini mendapatkan kurva nonlinear kuadratik pada korelasi kadar kotinin dan kolesterol LDL serum. Nilai adjusted $r^{2}$ penelitian ini sebesar 0,066 dengan nilai uji ANOVA 3.839 yang bermakna setelah memasukkan faktor perancu IMT dan mengeluarkan faktor perancu usia, jenis kelamin, dan indeks Brinkmann $(\mathrm{p}=0,012)$.

Temuan analisis multivariabel ini berhubungan dengan penelitian hubungan merokok dengan konsentrasi lipid/lipoprotein oleh Jain dan Ducatman (2018), yang mendapatkan nilai aOR rendah pada kejadian abnormalitas profil lipid pada perokok aktif. ${ }^{16}$ Penelitian tersebut memisahkan perokok aktif dari bukan perokok dengan memasukkan subyek ke kategori perokok aktif jika kadar kotininnya $>10 \mathrm{ng} / \mathrm{mL}$. Hal ini perlu diperhatikan, karena peneliti mendapatkan kadar kotinin serum subyek mahasiswa $10,5 \pm 6,8$ $\mathrm{ng} / \mathrm{mL}$, sehingga berada hampir tepat ditengah nilai cutoff yang ditetapkan penelitian Jain dan Ducatman (2018). Hal ini menunjukkan, karena nilai aOR yang rendah, kemungkinan terdapat korelasi nonlinear pada penelitian Jain dan Ducatman (2018) seperti yang didapatkan peneliti. Penelitian sebelumnya mengenai hubungan penggunaan tembakau dengan abnormalitas profil lipid telah dilakukan di India oleh Srivastava dan Garg (2015). Penelitian tersebut membandingkan profil lipid pengguna tembakau dengan kelompok kontrol, dimana diketahui rerata kadar kotinin serum memiliki hubungan bermakna dengan kadar kolesterol LDL serum abnormal $(\mathrm{t}=12.354, \mathrm{p}<0,001) .{ }^{9}$ penelitian sejenis juga telah dilakukan oleh Shrestha et al. (2019) yang membandingkan profil lipid pengguna tembakau jenis paan masala dengan kelompok kontrol. Hasil penelitian tersebut kadar kotinin urin berkorelasi positif dengan kadar kolesterol LDL serum pengguna tembakau dengan nilai $0,500(\mathrm{p}<001) .^{30}$

Hasil analisis deksriptif menunjukkan terdapat dua subyek yang memiliki nilai kolesterol LDL serum tertinggi dan merupakan outlier dalam data subyek yang berhasil dikumpulkan. dilakukan eksklusi pada data subyek tersebut dan hasil akhir didapatkan subyek berjumlah 122 orang.

Temuan kurva nonlinear pada penelitian ini membutuhkan penjelasan yang universal yang melibatkan perokok aktif dan pasif, karena subyek perokok aktif dan pasif tersebar pada rentang kadar rendah sampai tinggi kotinin serum dalam analisis bivariat dan multivariabel. Penjelasan ini dimulai dari variabel kotinin hingga kolesterol LDL serum. Kadar kotinin serum dapat berbeda antara individu yang disebabkan oleh lokasi terjadinya paparan asap rokok. ${ }^{8}$ Akan tetapi, ditemukannya kurva nonlinear dan kejanggalan bahwa kadar kotinin serum rendah berkorelasi dengan kadar kolesterol LDL yang lebih tinggi mengisyaratkan adanya mekanisme lain yang berperan, mekanisme itu adalah faktor metabolisme kotinin, yaitu kerja enzim CYP2A6 dan ekskresi kotinin di ginjal.22,31

Enzim CYP2A6 bertugas mengkonversi nikotin menjadi kotinin. ${ }^{22}$ Penelitian di Pakistan mengatakan adanya variasi konversi nikotin ke kotinin sebesar 55 - $92 \%$ antara satu orang dengan yang lain. ${ }^{32}$ Peningkatan kerja enzim CYP2A6 mengakibatkan peningkatan konversi nikotin ke kotinin. Hal ini dapat menimbulkan kerancuan dalam hasil akhir dan proses klasifikasi perokok aktif berdasarkan kadar kotinin serum, dimana seseorang dengan kotinin serum tinggi dianggap perokok aktif, padahal data laporan sendiri subyek menyatakan dirinya perokok pasif yang mungkin aktivitas metabolisme enzim CYP2A6 yang tinggi, seperti pada penelitian Jain dan Ducatman (2018). ${ }^{16}$ Faktor metabolisme kotinin lain adalah ekskresi kotinin ginjal, yang melibatkan proses filtrasi dan reabsorpsi. Terdapat variasi total klirens ginjal akan kotinin sebesar $43 \%$ yang disebabkan oleh faktor genetik additif. $^{23}$ Klirens kotinin oleh ginjal dapat ditingkatkan sampai $50 \%$ oleh proses asidifikasi urin ekstrim. ${ }^{28}$ Tingginya kadar kolesterol LDL serum pada kadar kotinin serum yang rendah mungkin disebabkan oleh penurunan kerja enzim 
CYP2A6 atau peningkatan ekskresi kotinin di ginjal.

Faktor diet mempengaruhi kerja enzim CYP2A6, yaitu konsumsi brokoli, dimana berefek meningkatkan kerja enzim..$^{22}$ Ekskresi kotinin juga diketahui dipengaruhi oleh faktor diet, yaitu konsumsi jus jeruk bali. ${ }^{28}$ Dalam penelitian ini, tidak dilakukan pendataan tentang riwayat diet subyek dan faktor lain yang mempengaruhi metabolisme kotinin.

Berdasarkan laporan American Heart Association tahun 2016, peningkatan kadar kolesterol LDL diketahui disebabkan oleh diet tinggi lemak jenuh atau lemak trans, kurangnya aktivitas, merokok, dan obesitas. Penyebab sekunder adalah obstruksi bilier, penyakit ginjal kronik, diabetes mellitus tipe 2, tekanan darah tinggi, dan hipotiroidisme. ${ }^{26}$ Dalam penelitian ini, riwayat adanya penyakit jantung dan kardiovaskuler, diabetes mellitus tipe 2, hiperkolesterolemia, dan konsumsi obat pengontrol kolesterol telah dieksklusi. Faktor farmakologis juga dapat berperan, seperti penggunaan diuretik, siklosporin, dan glukokortikoid. ${ }^{33}$ Faktor yang belum dianalisis dalam penelitian ini adalah konsumsi lemak jenuh, aktivitas fisik, dan riwayat penggunaan obat diuretik, siklosporin, dan glukokortikoid. Faktor stres juga diketahui berpengaruh terhadap perubahan kadar kolesterol LDL. ${ }^{33,34}$

Faktor resiko kolesterol LDL tinggi yang masih ada dalam penelitian ini adalah obesitas, terdiri dari 20 orang pria dan 11 orang wanita dari analisis univariat. Faktor obesitas ini diwujudkan sebagai nilai IMT dan dimasukkan ke dalam analisis multivariabel sebagai confounder. IMT memiliki nilai Standardized $\beta$ coefficient bermakna sebesar 0,197 ( $p=0,028)$. Faktor lain berupa seperti riwayat penyakit obstruksi bilier, penyakit ginjal kronik, hipertensi, dan hipertiroidisme tidak dianalisis di penelitian ini.

Selain faktor penyakit dan farmakologis, faktor diet juga berperan dalam peningkatan kadar kolesterol LDL, yaitu adalah kopi. Kopi diketahui berefek meningkatkan kadar kolesterol LDL. Penelitian mendapatkan Zat di dalam kopi bernama kafestol meningkatkan serum kolesterol sebesar 2,34 mg/dL dan kahweol sebesar 0,36 $\mathrm{mg} / \mathrm{dL}$, dimana kolesterol LDL mengisi $80 \%$ dari peningkatan kolesterol serum. Dalam penelitian ini tidak dimasukkan variabel confounding berupa kopi, tapi berdasarkan penelitian terbaru oleh Karabudak, Türközü, dan Köksal (2015), meminum kopi jenis instan tidak berpengaruh signifikan pada kadar profil lipid subyek penelitian. ${ }^{35}$

Penelitian korelasi status merokok yang menggunakan kotinin dan kolesterol LDL untuk membuktikan adanya pengaruh asap rokok yang mengandung nikotin terhadap resiko PJK yang berasal dari profil lipid telah dilakukan sebelumnya. 5,9,16,30 Penelitian lain mendapatkan hasil berbeda, dimana peningkatan kotinin serum memiliki korelasi tidak bermakna dengan profil lipid, yang disebabkan oleh desain penelitian potong lintang yang mengambil paparan asap rokok bersifat jangka pendek, sementara efek paparan asap rokok mungkin baru dapat dilihat dalam jangka panjang. ${ }^{29}$

Adanya pengaruh dari waktu pengukuran paparan asap rokok terhadap biomarker yang digunakan, menyebabkan perlunya biomarker dengan jangka waktu lebih lama dari kotinin serum atau biomarker faktor resiko PJK yang dapat dideteksi dalam jangka waktu pendek. Penelitian Benowitz et al. (2017) menemukan penggunaan kotinin urin sebagai biomarker paparan asap rokok lebih baik daripada kotinin serum karena berhasil mendeteksi $87 \%$ subyek remaja usia 13-19 tahun terpapar asap rokok dibanding penggunaan kotinin serum yang mendeteksi 55\% subyek dan laporan pribadi orangtua yang hanya mendeteksi $13 \%$ subyek terpapar asap rokok. ${ }^{36}$ Kotinin urin juga diketahui memiliki sensitivitas lebih tinggi daripada kotinin serum, karena konsentrasi pada urin 4-6 kali lebih tinggi daripada serum. ${ }^{37}$ Rokok tidak hanya menyebabkan resiko PJK lewat abnormalitas profil lipid, tapi juga remodelling jantung yang dibuktikan beberapa penelitian terdahulu. Penelitian Lourenço et al. (2018) menemukan adanya korelasi kotinin serum dengan lipid hidroperoksida (LH). LH adalah degradasi molekul lipid akibat kerusakan yang ditimbulkan stres oksidatif selama proses remodelling jantung akibat adanya paparan asap rokok. 38

Data yang dikumpulkan dari penelitian dengan desain potong lintang ini adalah yang pertama menunjukkan hubungan bermakna nonlinear antara kadar kotinin dan kolesterol LDL serum dari subyek yang tidak memiliki riwayat penyakit hiperkolesterolemia, diabetes mellitus, dan 
riwayat mengkonsumsi obat pengontrol kolesterol. Subyek dengan kadar kotinin rendah dan tinggi memiliki kadar kolesterol LDL yang lebih tinggi daripada subyek dengan kadar kotinin sedang.

\begin{tabular}{|c|c|c|c|}
\hline \multirow[b]{3}{*}{ Nature of association } & \multicolumn{3}{|c|}{ Relative risk of ischaemic heart disease $(95 \%$ Cl) } \\
\hline & \multirow[b]{2}{*}{ Passive smoking } & \multicolumn{2}{|c|}{ Active smoking } \\
\hline & & 1 cigarette per day & 20 cigarettes per day \\
\hline Overall (from figs 1 and 2)* & 1.30 (1.22 to 1.38$)$ & 1.39 (1.18 to 1.64$)$ & $1.78(1.31$ to 2.44$)$ \\
\hline Irreversible: contounding*' & $1.06(1.02$ to 1.10$)$ & $1.06(1.02$ to 1.10$)$ & $1.06(1.02$ to 1.10$)$ \\
\hline Reversible: cause and effect & 1.23 (1.14 to 1.33$)$ & $1.31 \uparrow(1.11$ to 1.55$)$ & $1.68+(1.23$ to 2.33$)$ \\
\hline
\end{tabular}

Gambar 5. Korelasi status perokok dengan resiko relatif kejadian PJK.

(sumber: Law MR, Morris JK, Wald NJ. Environmental tobacco smoke exposure and ischaemic. BMJ. 1997;315(October):973-80)

Penelitian berkaitan dengan hubungan nonlinear rokok dan efek yang ditimbulkannya dapat ditemui dari penelitian Law et al. (1997) tentang hubungan merokok dengan resiko PJK. Penelitian tersebut menemukan bukan perokok dengan paparan ETS rendah memiliki resiko terkena penyakit PJK sebesar 1,3 kali yang sama dengan perokok ringan (1 batang rokok/hari), sementara perokok berat (20 batang rokok/hari) memiliki resiko 1,78 kali. $^{39}$ Penelitian ini menemukan hubungan nonlinear dosis-respons antara paparan asap rokok dengan resiko PJK. Kotinin adalah surrogate marker (penanda pengganti) untuk paparan asap rokok, sementara kolesterol LDL adalah penanda pengganti untuk resiko PJK. Hal ini dapat menjadi dasar dalam meneliti hubungan nonlinear kotinin dan kolesterol LDL.

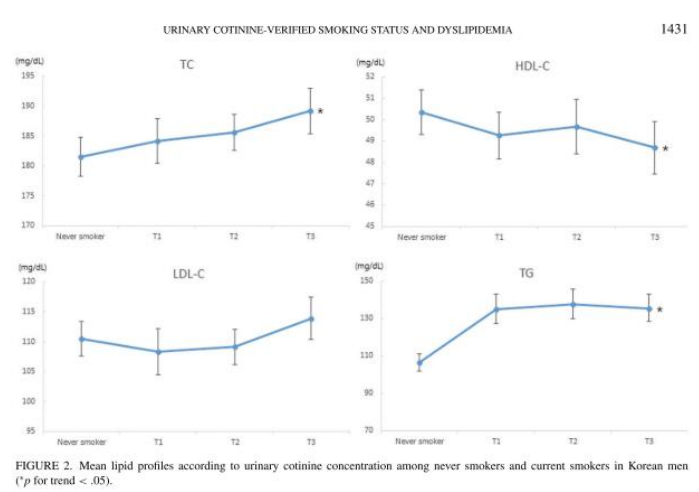

Gambar 6. Kurva korelasi kadar kotinin urin (ng/mL) dengan profil lipid (mg/dL) $(n=3231)$.

(sumber: Nam GE, Kim DH, Park YG, Han K, Choi YS, Kim SM, et al. Dose-related association between urinary cotinine-verified smoking status and dyslipidemia among Korean men: The 2008-2010 Korea National Health and Nutrition Examination Survey. Subst Use Misuse. 2014;49(11):1426-36.)
Penelitian Nam et al. (2014) menggunakan data penduduk pria dalam KNHANES 2008-2010 berhasil menemukan adanya kurva nonlinear pada hubungan jenis perokok berdasarkan kotinin urin dengan kadar kolesterol LDL serum, tapi nilai uji komparatif dan odd ratio (OR) ini tidak bermakna, kemungkinan disebabkan oleh kurangnya data confounding yang dapat ditambahkan ke dalam analisis untuk dilakukan

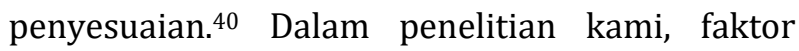
perancu berbeda dengan yang terdapat di penelitian Nam et al. (2014), yang mana faktor perancu itu berhasil meningkatkan nilai signifikansi korelasi sekaligus regresi multipel.

Penjelasan hubungan kadar kotinin serum rendah dengan kolesterol LDL serum tinggi dapat dijelaskan sesuai dengan faktor yang telah diketahui berhubungan yang dibuktikan dari penelitian terdahulu. Hubungan nonlinear pada penelitian ini selain dapat disebabkan oleh variabel perancu, juga kemungkinan disebabkan oleh adanya hormesis. Hormesis adalah suatu konsep tentang sistem biologis yang dapat merespon positif, atau dapat distimulasikan oleh paparan fisik maupun biologis obat dalam kadar rendah, yang mana pada kadar tinggi obat itu bersifat toksik. ${ }^{41}$

Pada tahun 1888, farmakolog Hugo Schulz mengamati dosis kecil dari beberapa desinfektan kimia merangsang pertumbuhan ragi. ${ }^{42,43}$ Hormesis yang secara keseluruhan merupakan kurva dosis-respons berbentuk bifasik telah terjadi secara umum di beberapa penelitian terdahulu, seperti bakteri yang lebih mudah tumbuh pada antibiotik jumlah sedikit dan perlakuan iskemik waktu singkat pada jaringan tubuh manusia yang memberikan resistensi terhadap kehancuran tindakan reperfusi jangka waktu lama. ${ }^{44,42,45}$ Hormesis secara objektif hanyalah sebuah fenomena atau gejala, bukan sebuah diagnosis dan perlu dicari mekanisme dasar penyebab terjadinya hormesis. ${ }^{46}$ Dalam penelitian ini, kurva berbentuk $U$ berhasil didapatkan dari korelasi kadar kotinin dan kolesterol LDL serum, tapi belum dapat dikatakan hormesis yang disebabkan korelasi ini tidak bersifat langsung karena kotinin yang digunakan sebagai biomarker nikotin.

Pembuktian adanya hormesis dilakukan melalui penelitian eksperimental yang idealnya menggunakan rentang dosis yang luas dan 
melibatkan banyak sampel dan eksperimen. Eksperimen kinetik multipel juga diperlukan untuk mendapatkan informasi yang tepat mengenai jangka waktu terbaik sejak penyakit muncul bagi obat memberikan efek maksimal. 46 Penelitian ini menemukan adanya kurva berbentuk $U$ yang merupakan salah satu ciri hormesis, tapi belum dapat disimpulkan adanya hormesis karena penelitian ini bersifat analitik observasional. ${ }^{47}$

Korelasi kotinin dan kolesterol LDL serum berhasil diidentifikasi dalam penelitian analitik observasional ini dengan adanya temuan tambahan berupa korelasi dengan kurva nonlinear. Walaupun korelasi ini bermakna, diperlukan penelitian eksperimental dengan desain yang lebih baik untuk bisa membuktikan benar adanya hubungan dosis-respons antara kotinin dan kolesterol LDL. Untuk penelitian tentang biomarker untuk menilai resiko PJK dapat digunakan variabel dependen lain yang berkaitan dengan proses stres oksidatif seperti pada penelitian korelatif antara kotinin serum dan LH. 38

\section{Simpulan}

Berdasarkan hasil penelitian yang telah didapatkan dan dipaparkan sebelumnya, dapat disimpulkan bahwa subyek mahasiswa Universitas Andalas memiliki kadar kotinin serum yang berada dibawah nilai ambang batas perokok aktif sesuai penelitian Jain dan Ducatman (2018).16 Subyek penelitian memiliki kadar kolesterol LDL serum normal berdasarkan NCEPATP III. ${ }^{24}$

Pada analisis multivariabel, terdapat korelasi bersifat nonlinear yang bermakna antara kadar kotinin dan kolesterol LDL serum pada subyek penelitian.

\section{Ucapan Terima Kasih}

Terimakasih kepada semua pihak yang telah memberikan waktu, tenaga, dan doa yang memberikan kontribusi dalam penelitian ini hingga dapat dilaksanakan dengan baik.

\section{Daftar Pustaka}

1. WHO. WHO global report on trends in tobacco smoking 2000-2025. Geneva; 2015.

2. Balitbangkes RI. Pokok-pokok hasil Riskesdas Indonesia tahun 2013. Balitbangkes Kemenkes RI: Jakarta, 2013.
3. Tessier JF, Freour P, Belougne D, Crofton J. Smoking Habits and Attitudes of Medical Students towards Smoking and Antismoking Campaigns in Nine Asian Countries. Int. J. Epidemiol. 1992;21(2):298-304.

4. The WHO FCTC Indicators : Global Health Professions Student Survey ( Medical ), 2005 - 2009. 2009.

5. Devaranavadgi BB, Aski BS, Kashinath T, Hundekari A. Effect of Cigarette Smoking on Blood Lipids - A Study in Belgaum, Northern Karnataka, India. Glob. J. Med. Res. 2012;12(6):56-61.

6. Silveira Balbani AP, Montovani JC. Methods for smoking cessation and treatment of nicotine dependence. Braz. J. Otorhinolaryngol. 2005;71(6):820-6.

7. Nian H, Wang J, Wu H, Lo JG, Chiu KH, Pounds JG, et al. Electrochemical immunoassay of cotinine in serum based on nanoparticle probe and immunochromatographic strip. Anal. Chim. Acta. 2012;713:50-5.

8. Attard R, Dingli P, Doggen CJM, Cassar K, Farrugia R, Wettinger SB. The impact of passive and active smoking on inflammation, lipid profile and the risk of myocardial infarction. Open Hear. 2017;4(2):1-8.

9. Srivastava A, Garg G. Serum Cotinine Concentration and Serum Lipid Profile: Risk for Cardiovascular Disease in Smokeless Tobacco Users. Int. J. Sci. Study. 2015;3(5):63-7.

10. Hays WL. Review of Using Multivariate Statistics. Vol. 28, Contemporary Psychology: A Journal of Reviews. 1983.

11. Ilmiawati C, Reza M, Yanni M, Rusjdi DA. Blood Cd levels and carotid intima-media thickness in young adults living in Padang, Indonesia. BMC Res. Notes. 2020;13(1):1-7.

12. Julius U, Dittrich M, Pietzsch J. Factors influencing the formation of small dense low-density lipoprotein particles in dependence on the presence of the metabolic syndrome and on the degree of glucose intolerance. Int. J. Clin. Pract. 2007;61(11):1798-804.

13. Lind L, Sundström J, Ärnlöv J, Lampa E. Impact of aging on the strength of cardiovascular risk factors: A longitudinal study over 40 years. J. Am. Heart Assoc. 2018;7(1).

14. Abbott RD, Garrison RJ, Wilson PWF, Epstein FH, Castelli WP, Feinleib M, et al. Joint distribution of lipoprotein cholesterol classes. The Framingham study. Arteriosclerosis. 1983;3(3):260-72.

15. Wang X, Magkos F, Mittendorfer B. Sex differences in lipid and lipoprotein metabolism: It's not just about sex hormones. J. Clin. Endocrinol. Metab. 2011;96(4):885-93.

16. Jain RB, Ducatman A. Associations between smoking and lipid / lipoprotein concentrations among US adults aged ! 20 years. 2018;7:1-10.

17. Yan-Ling Z, Dong-Qing Z, Chang-Quan H, Bi-Rong D. Cigarette smoking and its association with serum lipid/lipoprotein among Chinese nonagenarians/centenarians. Lipids Health Dis. 2012;11(1):1.

18. Mohammed Abd Ahmed Rashan O. The Impact of Cigarette Smoking on Lipid Profile among Iraqi Smokers. Int. J. Collab. Res. Intern. Med. Public Heal. 2016;8(8):491-500.

19. Baltar VT, Xun WW, Chuang SC, Relton C, Ueland PM, Vollset SE, et al. Smoking, secondhand smoke, and cotinine levels in a subset of EPIC cohort. Cancer Epidemiol. Biomarkers Prev. 2011;20(5):869-75.

20. Benowitz NL, Bernert JT, Caraballo RS, Holiday DB, 
Wang J. Optimal serum cotinine levels for distinguishing cigarette smokers and nonsmokers within different racial/ethnic groups in the United States between 1999 and 2004. Am. J. Epidemiol. 2009;169(2):236-48.

21. Moyer TP, Charlson JR, Enger RJ, Dale LC, Ebbert JO, Schroeder DR, et al. Simultaneous analysis of nicotine, nicotine metabolites, and tobacco alkaloids in serum or urine by tandem mass spectrometry, with clinically relevant metabolic profiles. Clin. Chem. 2002;48(9):1460-71.

22. Tanner JA, Tyndale RF. Variation in CYP2A6 activity and personalized medicine. J. Pers. Med. 2017;7(4):129.

23. Benowitz NL, Lessov-Schlaggar CN, Swan GE. Genetic influences in the variation in renal clearance of nicotine and cotinine. Clin. Pharmacol. Ther. 2008;84(2):243-7.

24. National Cholesterol Education Program. Third Report of the National Cholesterol Education Program (NCEP) Expert Panel on Detection, Evaluation, and Treatment of High Blood Cholesterol in Adults (Adult Treatment Panel III). Vol. 108, Postgraduate Medicine. 2000. Available from: https://www.nhlbi.nih.gov/files/docs/guidelines/at p3xsum.pdf

25. Ashley L. Merianos, Jandarov RA, Khoury JC, Mahabee-Gittens EM. Tobacco Smoke Exposure Association with Lipid Profiles and Adiposity Among U.S. Adolescents. Physiol. Behav. 2017;176(1):13948.

26. Update AHAS. Heart Disease and Stroke Statistics 2018 Update A Report From the American Heart Association. 2018.

27. Permenkes No 28 Tahun 2019. Angka Kecukupan Gizi yang Dianjurkan untuk Masyarakat Indonesia. Jakarta: Bidang Hukum dan Perundang-undangan; 2019.

28. Benowitz NL, Hukkanen J, Iii PJ. Nicotine Chemistry metabolism and kinetics. Handb Exp Pharmacol. 2010;192:29-60.

29. Kim S, Kang SH, Han D, Kim SH, Kim HJ, Park JJ, et al. Relation between secondhand smoke exposure and cardiovascular risk factors in never smokers. J. Hypertens. 2017;35(10):1976-82.

30. Shrestha S, Mishra DR, Dhakal N, Bhandari S, Khanal S, Lamsal M. Correlation of urinary cotinine with cardiovascular risk factors in pan masala tobacco users. Indian Heart J. 2019;(xxxx):1-5.

31. Benowitz NL, St. Helen G, Dempsey DA, Jacob P, Tyndale RF. Disposition kinetics and metabolism of nicotine and cotinine in African American smokers: Impact of CYP2A6 genetic variation and enzymatic activity. Pharmacogenet. Genomics. 2016;26(7):34050.

32. Baig S, Rubab Z. Relation of Serum Cotinine with Passive Smoking. PakJ Med Dent. 2014;3(3):8-12.

33. Zhang X, Hu D. Comments for 2013 ACC/AHA Guideline on the Treatment of Blood Cholesterol to Reduce Atherosclerotic Cardiovascular Risk in Adults. Zhonghua nei ke za zhi. 2015;54(1):9-12.

34. Marcondes FK, das Neves VJ, Costa R, Sanches A, Sousa T, Sampaio Moura MJC, et al. Dyslipidemia Induced by Stress. In: Dyslipidemia - From Prevention to Treatment. 2012.

35. Karabudak E, Türközü D, Köksal E. Association between coffee consumption and serum lipid profile. Exp. Ther. Med. 2015;9(5):1841-6.
36. Benowitz NL, Jain S, Dempsey DA, Nardone N, Helen GS, Jacob P. Urine cotinine screening detects nearly ubiquitous tobacco smoke exposure in urban adolescents. Nicotine Tob. Res. 2017;19(9):1048-54.

37. Avila-Tang E, Elf JL, Cummings KM, Fong GT, Hovell MF, Klein JD, et al. Assessing secondhand smoke exposure with reported measures. Tob. Control. 2013;22(3):156-63.

38. L MAM, Braz MG, Aun AG, Pereira BLB, Fernandes FH, Kazmarek EM, et al. Lipid damage is the best marker of oxidative injury during the cardiac remodeling process induced by tobacco smoke. BMC Pharmacol. Toxicol. 2018;19(1):74.

39. Law MR, Morris JK, Wald NJ. Environmental tobacco smoke exposure and ischaemic. BMJ. 1997;315(October):973-80.

40. Nam GE, Kim DH, Park YG, Han K, Choi YS, Kim SM, et al. Dose-related association between urinary cotinine-verified smoking status and dyslipidemia among Korean men: The 2008-2010 Korea National Health and Nutrition Examination Survey. Subst. Use Misuse. 2014;49(11):1426-36.

41. Baldwin J, Grantham V. Radiation hormesis: Historical and current perspectives. J. Nucl. Med. Technol. 2015;43(4):242-6.

42. Calabrese EJ. Historical blunders: How toxicology got the dose-response relationship half right. Cell. Mol. Biol. 2005;51(7):643-54.

43. Calabrese EJ, Baldwin LA. Defining hormesis. Hum. Exp. Toxicol. 2002;21(2):91-7.

44. Farland W, Pro- E, Cal- E, Corp E, Hormesis M, Arndt $\mathrm{R}$, et al. Sipping From a Poisoned Chalice. Science (80.). 2003;302(5644):376-377+379.

45. DeGracia DJ, Montie HL. Cerebral ischemia and the unfolded protein response. J. Neurochem. 2004;91(1):1-8.

46. Mao L, Franke J. Hormesis in aging and neurodegeneration-a prodigy awaiting dissection. Int. J. Mol. Sci. 2013;14(7):13109-28.

47. Calabrese EJ. Hormesis: Why it is important to toxicology and toxicologists. Environ. Toxicol. Chem. 2008;27(7):1451-74. 